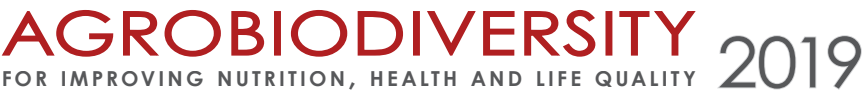

(3)

\section{EVALUATION OF THE IN VITRO ANTIMICROBIAL ACTIVITY OF ETHANOLIC EXTRACTS DERIVED FROM LEAVES OF CAMELLIA JAPONICA CULTIVARS (THEACEAE) AGAINST ENTEROBACTER CLOACAE STRAIN}

\author{
Kharchenko Igor ${ }^{1}$, Tkachenko Halyna* ${ }^{2}$, Buyun Lyudmyla ${ }^{1}$, \\ Kurhaluk Natalia ${ }^{2}$, Góralczyk Anna ${ }^{2}$, Maryniuk Myroslava ${ }^{1}$, \\ Tomin Vładimir ${ }^{3}$, Osadowski Zbigniew ${ }^{2}$ \\ ${ }^{1}$ M.M. Gryshko National Botanic Garden, National Academy of Science of Ukraine, Kyiv, Ukraine
${ }^{2}$ Institute of Biology and Earth Sciences, Pomeranian University in Słupsk, Poland
${ }^{3}$ Department of Physics, Pomeranian University in Słupsk, Poland
}

Received: 15. 11. 2019 Revised: 3. 12. $2019 \quad$ Published: 6. 12. 2019

The increasing incidence of antibiotic resistance among bacterial and fungal pathogens necessitates plants as an alternative therapy in restricting the resistant infectious organisms. The present study was undertaken to determine the antibacterial activity of ethanolic extracts derived from the leaves of Camellia japonica cultivars. The aim of the presented study was to assess the in vitro antimicrobial activity of ethanolic extracts derived from the leaves of $C$. japonica 'Kramer's Supreme', 'C.M. Wilson', 'La Pace', 'Mrs. Lyman Clarke', 'Benikarako', 'Fanny Bolis' against clinical cefuroxime-resistant Enterobacter cloacae strain. Ethanolic extracts were prepared by freshly crushed leaves and evaluated for their antimicrobial activity against Enterobacter cloacae strain locally isolated using disc diffusion assay. Among the six plant extracts screened, C. japonica 'Mrs. Lyman Clarke' exhibited the highest inhibitory zones against the tested strain (the mean value of the zone of inhibition was $12.5 \pm 0.7 \mathrm{~mm}$ ). The least activity is attributed to $C$. japonica 'La Pace' extract. Based on our current investigations it can be concluded that $C$. japonica and its cultivars possess a mild antibacterial efficacy. This mild activity on the E. cloacae, Gram-negative organisms, is most likely due to the protective nature of the outer membrane of their cell walls. It may also be assumed that the antimicrobial potential of various samples of these plants might be due to a wide variety of compounds present in these plants. The findings reported herein give scientific credence to the traditional uses of these plants and suggest that extracts derived from the leaves of $C$. japonica and its cultivars merit further phytochemical study as natural antibiotics to identify the secondary metabolites.

Keywords: Camellia japonica L., leaves, Enterobacter cloacae, antibacterial activity, disc diffusion technique, ethanolic extracts

\footnotetext{
*Corresponding author: Halyna Tkachenko, Institute of Biology and Earth Sciences, Pomeranian University in Słupsk, Arciszewski 22b, 76-200 Słupsk, Poland $\triangle$ tkachenko@apsl.edu.pl
} 


\section{Introduction}

Despite the alarming rise in antimicrobial resistance over the last decades, resistance to antimicrobial drugs is nothing new (Carranza et al., 2015). Subsequent antibiotics use resulting in the emergence of resistant bacterial strains one to four years after their introduction and pose a greater threat to public health (Reddick and Alto, 2014). Therefore, alternative strategies must be considered if antimicrobial resistance is to be successfully combated. One alternative is the use of medicinal plants, which for many cultures continue to play a crucial role in the primary care of patients (Farnsworth, 1990; Fabricant and Farnsworth, 2001). Ethnobotany, ethnomedicine, and traditional medicine can provide information that is useful as a 'pre-screen' to select plants for experimental pharmacological studies (Farnsworth, 1990). It is widely accepted that the antimicrobial activities and physiological effects from plant therapies are due to the biosynthesis of secondary metabolites produced by plants as a defense mechanism. Secondary metabolites play a major role in the adaptation of plants to the environment and in overcoming stress conditions (Ramakrishna and Ravishankar, 2011).

Camellia L., containing about 280 species, is a genus with high economic, ecological and phylogenetic values in the family Theaceae (Vijayan et al., 2009; Yang et al., 2013). It is native to Southern, Eastern Asia and China, which possess more than $80 \%$ of the species and are the center of species diversity (Gao et al., 2005).

Among the Camellia species, the economic value of the $C$. japonica L. ranks the highest due to its beautiful ornamental flowers and medicinal properties. It is native to South Korea, Japan, and China. Camellia japonica, which comprises thousands of cultivars, is the most widely cultivated species. Besides, it has been used in traditional medicine in Japan, China, and Korea (Yoon et al., 2017). Extensive studies have been conducted in order to assess the phytochemical composition of various parts of $C$. japonica plants, including saponins in its fruits and seeds and triterpenes in its flowers and seed oil (Akihisa et al., 1997; Yoon et al., 2017). It has been reported that leaves of $C$. japonica possess antioxidant, antifungal, and cytotoxic properties (Park et al., 2002; Thao et al., 2010; Onodera et al., 2016).

Green tea (Camellia sinensis L.) has received much attention as a beverage worldwide during the last few decades due to its various beneficial effects on human health, including different types of cancer, heart disease, and liver disease, etc. (Chacko et al., 2010; Bashir et al., 2014). Studies reveal that green tea possesses diverse pharmacological properties to lower the incidence of metabolic syndromes, such as obesity, type II diabetes, and cardiovascular risk factors (Chacko et al., 2010). Tea leaves have been reported to contain over 700 bioactive compounds of which one third is contributed by polyphenols (Khan and Mukhtar, 2007; Vijayan et al., 2009; Mahmood et al., 2010).

Long-term consumption of tea catechins could be beneficial against high-fat diet-induced obesity and type II diabetes and could reduce the risk of coronary disease (Chacko et al., 2010). Green tea was also reported as useful against HIV strains (Fassina et al., 2002). An aqueous extract of Camellia sinensis found to be effective against Gram-positive, Gramnegative, and fungi (Khan et al., 2019). The most important finding of this study is its aqueous extract inhibitory effect against drug-resistant microorganisms, e.g. methicillin-resistant 
Staphylococcus aureus (MRSA), Pseudomonas aeruginosa, and Candida albicans (Khan et al., 2019).

Species of the Enterobacter cloacae complex are widely encountered in nature. They can act as pathogens (Mezzatesta et al., 2012). Today, 22 species belong to the Enterobacter genus (Davin-Regli et al., 2019). During the last three decades, Enterobacter aerogenes and E. cloacae have been reported as important opportunistic and multi-resistant bacterial pathogens for humans in hospital wards (Davin-Regli and Pagès, 2015). The biochemical and molecular studies on E. cloacae have shown genomic heterogeneity, comprising six species: Enterobacter cloacae, Enterobacter asburiae, Enterobacter hormaechei, Enterobacter kobei, Enterobacter ludwigii, and Enterobacter nimipressuralis, E. cloacae and E. hormaechei are the most frequently isolated in human clinical specimens (Mezzatesta et al., 2012). These species are also described in the environment and have been reported as opportunistic pathogens in plants, animals, and humans (Davin-Regli et al., 2019). The dissemination of Enterobacter sp. is associated with the presence of redundant regulatory cascades that efficiently control the membrane permeability ensuring the bacterial protection and the expression of detoxifying enzymes involved in antibiotic degradation/inactivation (DavinRegli and Pagès, 2015).

Enterobacter is a versatile bacterium able to promptly respond to the antibiotic treatment in the colonized patient (Davin-Regli and Pagès, 2015). It is able to manage different mechanisms of resistance via various local and global regulator genes and the modulation of the expression of different proteins, including enzymes ( $\beta$-lactamases, etc.) or membrane transporters, such as porins and efflux pumps (Davin-Regli et al., 2019). In fact, they are capable of overproducing AmpC $\beta$-lactamases by derepression of a chromosomal gene or by the acquisition of a transferable ampC gene on plasmids conferring the antibiotic resistance. Many other resistance determinants that are able to render ineffective almost all antibiotic families have been recently acquired (Mezzatesta et al., 2012). In addition, these bacterial species are able to acquire numerous genetic mobile elements that strongly contribute to antibiotic resistance (Davin-Regli and Pagès, 2015).

Increasing resistance among pathogens to conventional antibiotics and undesirable side effects of existing therapies have made traditional medicinal plants an attractive source to screen for antimicrobial agents (Choi et al., 2017).

In line with this effort, the present study was aimed to determine the antibacterial activity of six cultivars Camellia japonica against clinical cefuroxime-resistant Enterobacter cloacae strain.

\section{Materials and methodology}

\section{Collection of Plant Material}

The leaves of cultivars Camellia japonica 'Kramer's Supreme', 'C.M.Wilson', 'La Pace, 'Mrs. Lyman Clarke, 'Benikarako', 'Fanny Bolis' cultivated under glasshouse conditions, were sampled at M.M. Gryshko National Botanical Garden (Kyiv, Ukraine). 

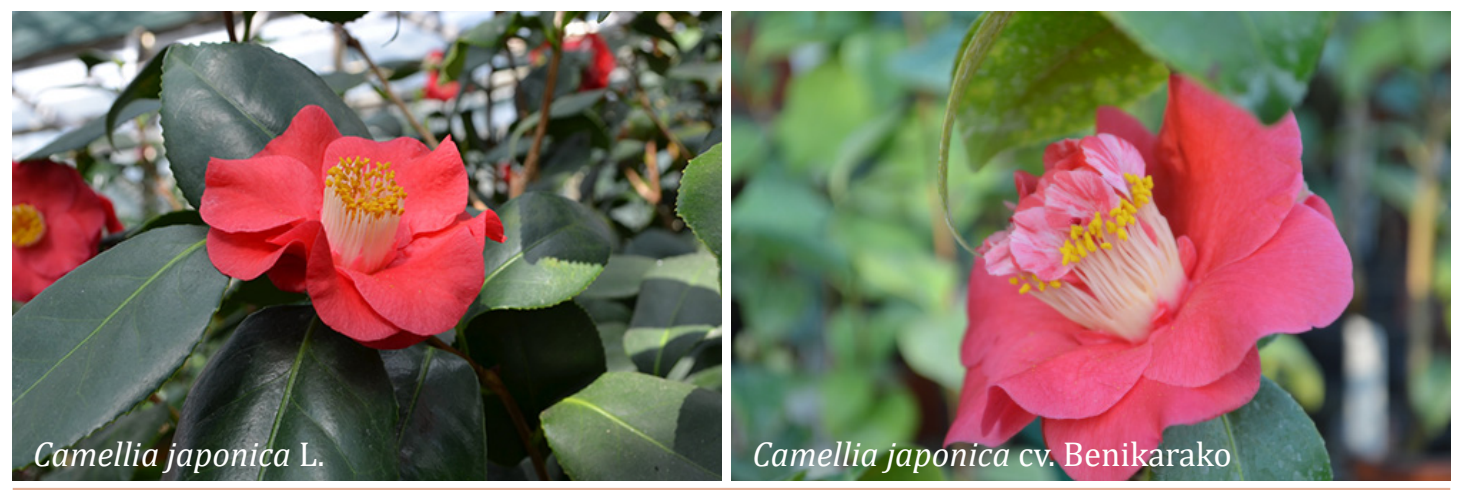

Figure 1 Camellia japonica L. plants cultivated at the glasshouses of M.M. Gryshko National Botanic Garden, NAS of Ukraine

\section{Preparation of Plant Extracts}

The collected leaves were brought into the laboratory for antimicrobial studies. Freshly crushed leaves were washed, weighed, and homogenized in 96\% ethanol (in proportion $1: 19$ ) at room temperature. The extracts were then filtered and investigated for their antimicrobial activity.

\section{Bacterial strain}

The testing of the antibacterial activity of the plant extract was carried out in vitro by the Kirby-Bauer disc diffusion technique (Bauer et al., 1966). The non-repetitive clinical strain of cefuroxime-resistant E. cloacae isolated from bloodstream infection was collected from Koszalin Hospital during March-April, 2019. The purity, as well as the identity of isolate, was confirmed in the laboratory conditions by standard microbiological methods and were interpreted according to the guidelines of the Clinical Laboratory Standards Institute (2014).

Susceptibility testing of the isolates was performed by the disk diffusion technique according to the Guidelines of Clinical and Laboratory Standard Institute (CLSI). The antibiotics tested were piperacillin, piperacillin-tazobactam, cefepime, cefotaxime, ceftazidime, cefuroxime, aztreonam, imipenem, meropenem, ertapenem, amikacin, gentamicin, trimethoprimsulphamethoxazole, ciprofloxacin, levofloxacin, tetracycline, tigecycline, and polymyxin B. Results were interpreted according to CLSI criteria. MIC was determined by $E$-test strips (according to manufacturer's instruction) and agar dilution method (according to the Guidelines of Clinical and Laboratory Standard Institute). The resistance breakpoints were the same as the ones defined by the National Committee for Clinical Laboratory Standards (NCCLS, 2014).

Enterobacter cloacae strain studied was resistant to amoxicillin, cefuroxime, trimethoprimsulphamethoxazole, and cefotaxime.

\section{The Disk Diffusion Method for Evaluation of Antibacterial Activity of Plant Extracts}

Strain tested was plated on TSA medium (Tryptone Soy Agar) and incubated for $24 \mathrm{hr}$ at $37^{\circ} \mathrm{C}$. Then the suspension of microorganisms was suspended in sterile PBS and the turbidity 
adjusted equivalent to that of a $0.5 \mathrm{McF}$ arland standard. The antimicrobial susceptibility testing was done on Muller-Hinton agar by the disc diffusion method (Kirby-Bauer disk diffusion susceptibility test protocol). Muller-Hinton agar plates were inoculated with $200 \mu \mathrm{l}$ of standardized inoculum (108 CFU/mL) of the bacterium and spread with sterile swabs.

Sterile filter paper discs impregnated by extract were applied over each of the culture plates, 15 min after bacteria suspension was placed. A negative control disc impregnated by sterile $96 \%$ ethanol was used in each experiment. After culturing bacteria on Mueller-Hinton agar, the disks were placed on the same plates and incubated for $24 \mathrm{hr}$ at $37^{\circ} \mathrm{C}$. The assessment of antimicrobial activity was based on the measurement of the diameter of the inhibition zone formed around the disks. The diameters of the inhibition zones were measured in millimeters and compared with those of the control and standard susceptibility disks. The activity was evidenced by the presence of a zone of inhibition surrounding the well.

\section{Statistical analysis}

Zone diameters were determined and averaged. Statistical analysis of the data obtained was performed by employing the mean. All variables were randomized according to the phytochemical activity of extracts tested. All statistical calculation was performed on separate data from each extract. The data were analyzed using a one-way analysis of variance (ANOVA) using Statistica software, version 8.0 (StatSoft, Poland) (Zar, 1999). The following zone diameter criteria were used to assign susceptibility or resistance of bacteria to the phytochemicals tested: Susceptible $(S) \geq 15 \mathrm{~mm}$, Intermediate $(I)=10-15 \mathrm{~mm}$, and Resistant (ㅁ) $\leq 10 \mathrm{~mm}$ (Okoth et al., 2013).

\section{Results and discussion}

Figure 2 and 3 summarize the results of bacterial growth inhibition of E. cloacae by ethanol extract derived from the leaves of various $C$. japonica cultivars.

The crude extracts were analyzed for their antibacterial effect by the determination of their inhibitory zones against $E$. cloacae strain. Of the six plant extracts screened, $C$. japonica 'Mrs. Lyman Clarke' exhibited the highest inhibitory zones against the tested strain (the mean of the zone of inhibitions was $12.5 \pm 0.7 \mathrm{~mm}$ ). The $C$. japonica 'Benikarako', 'Fanny Bolis', and 'Kramer's Supreme' exhibited zone of inhibitions $10.3 \pm 0.7,10.6 \pm 0.6,10.2 \pm 0.6 \mathrm{~mm}$ against E. cloacae strain, respectively, as shown in Figure 2. The antibacterial effect of $C$. japonica 'La Pace' was almost comparable to the effects of positive control $(9.1 \pm 0.5 \mathrm{~mm})$. The least activity is attributed to $C$. japonica 'La Pace' extract.

In this study, we investigated the antimicrobial activity of plant extracts by agar well diffusion. In our study, Camellia japonica 'Kramer's Supreme', 'C.M. Wilson', 'La Pace,, 'Mrs. Lyman Clarke,' 'Benikarako', 'Fanny Bolis' were less potent against the test bacterium as can be assumed from the observed zone of growth inhibitions of Enterobacter cloacae. It is noteworthy to mention that this mild activity on the E. cloacae, Gram-negative organisms, is most likely due to the protective nature of the outer membrane of their cell walls. Hence, these extracts may not have good candidates as drugs lead for antibacterial activity because of these high values of 
diameters of inhibition zone due to the importance of the potency of the antibacterial agent in drug development, amongst other factors.

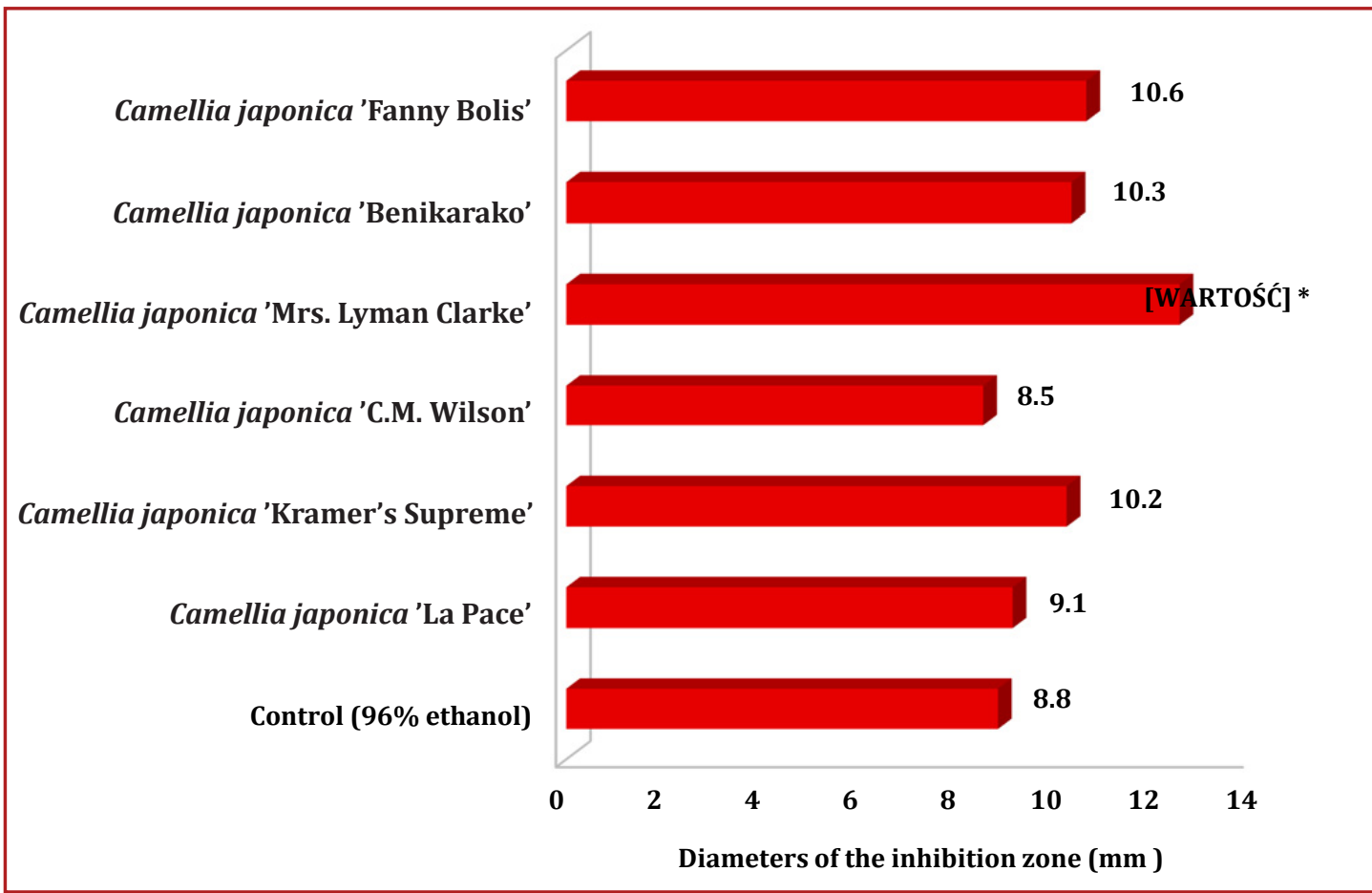

Figure 2 Zone of growth inhibitions of Enterobacter cloacae induced by the extracts obtained from leaves of various Camellia cultivars in millimeter $(n=8)$

* changes are statistically significant $(p<0.05)$ compared to $96 \%$ ethanol (control)

In a separate study, we tested these extracts for toxic effects on human erythrocytes. C. japonica and its cultivars were found to be non-toxic on the concentrations tested for antimicrobial activity (data not shown). Results obtained in our previous study showed that there is a possibility of using extracts derived from leaves of various $C$. japonica cultivars in intensive aquaculture farms. Leaf extracts of Camellia japonica may be used as an antioxidant agent in aquaculture. The lipid peroxidation (2-thiobarbituric acid reactive substances (TBARS) as biomarker) level in the muscle tissue of rainbow trout (Oncorhynchus mykiss Walbaum) after incubation with extracts obtained from leaves of various Camellia japonica cultivars was evaluated in our previous study (Kharchenko et al., 2017a). Moreover, all extracts (except $C$. japonica 'Benikarako' and 'Fanny Bolis') reduced the TBARS level in the extracts-treated muscle tissue, but these results were non-significant. Furthermore, the use of such plant products as antioxidants and immunostimulants in aquaculture systems may also have environmental value because of their biodegradability (Kharchenko et al., 2017a). The superoxide dismutase (SOD) activity, an antioxidant enzyme, was increased in the muscle tissue after incubation with $C$. japonica 'Kramer's Supreme' extract (by 52\%, $p=0.004$ ), 'C.M. Wilson' (by 88\%, $p=0.001$ ), 'Mrs. Lyman Clarke' (by 87.2\%, $p=0.000$ ), and 'Fanny Bolis' (by $40.7 \%, p=0.044$ ) compared to the control group. The SOD activity in the muscle tissue 
Kharchenko, I., Tkachenko, H., Buyun, L., Kurhaluk, N., Góralczyk, A., Maryniuk, M., Tomin, V., Osadowski, Z. Agr.bio.div. Impr. Nut., Health Life Qual., 2019, 333-347
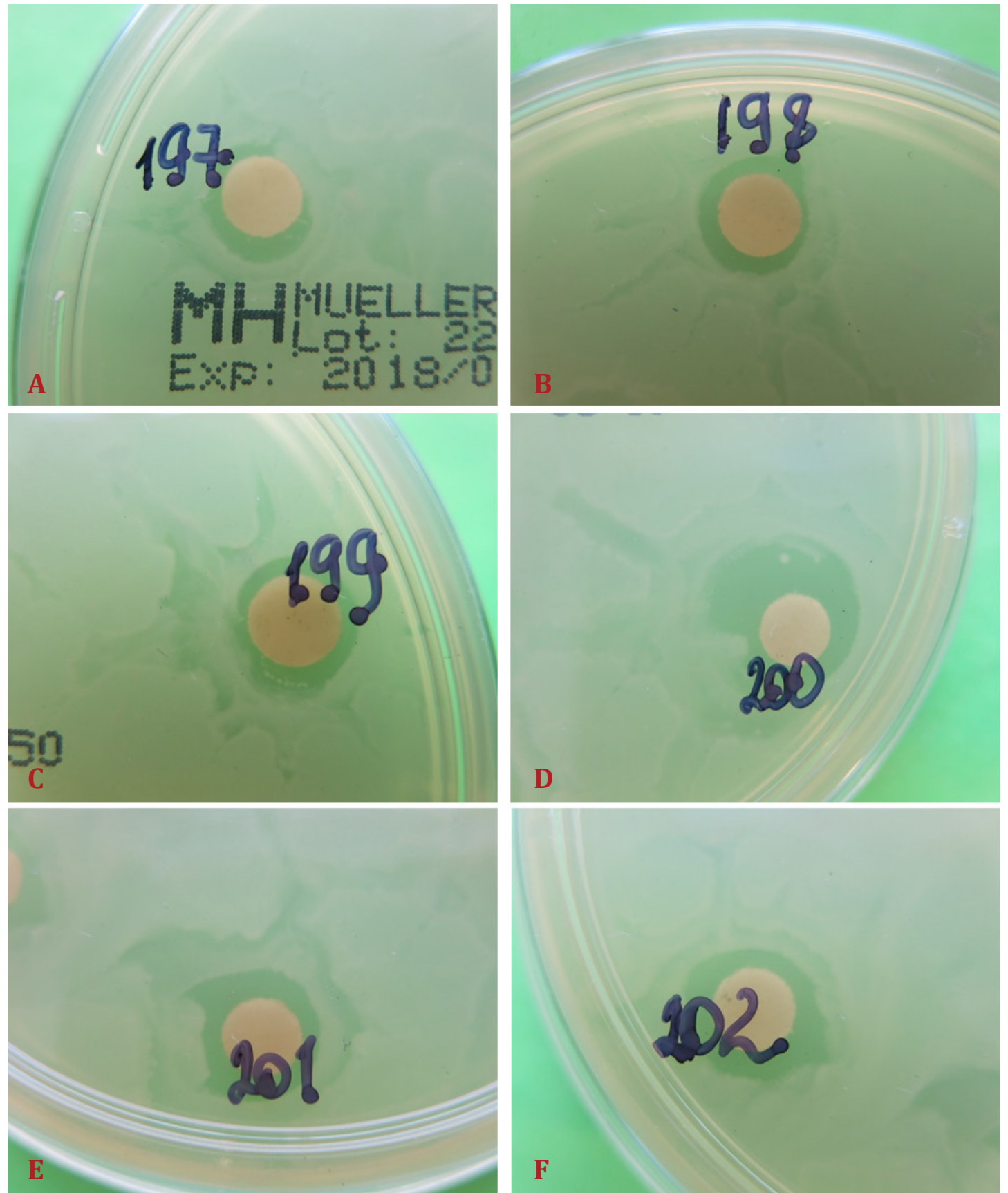

Figure 3 Antimicrobial activity of ethanolic extracts of various Camellia cultivars analyzed by KirbyBauer disc-diffusion assay: Camellia japonica 'La Pace' (A), 'Kramer's Supreme' (B), 'C.M. Wilson' (C), 'Mrs. Lyman Clarke' (D), 'Benikarako' (E), and 'Fanny Bolis' (F) 
after incubation with Camellia japonica 'La Pace' and 'Benikarako' was also non-significantly increased by 31.5 and 27.3\% ( $p<0.05$ ), respectively (Kharchenko et al., 2018). The results of the investigation revealed quite a high level of total antioxidant capacity (TAC) in samples of muscle tissue incubated with leaf extracts of $C$. japonica 'C.M. Wilson' and 'Benikarako' cultivars. The levels of TAC were increased by 41.7 and $44.8 \%(p<0.05)$ as compared with a control group of muscle tissue homogenates. Leaf extracts of $C$. japonica 'La Pace' and 'Kramer's Supreme' cultivars being incubated with muscle tissue have not changed the level of TAC, while the effect of the leaves extracts of $C$. japonica 'Mrs. Lyman Clarke' and 'Fanny Bolis' on the decreasing of TAC level was insignificant $(p>0.05)$. The results of the study suggested the high antioxidant capacity of Camellia cultivars screened give reason to believe that application of these plant extracts signifies a rational curative strategy to prevent and cure various fish diseases involving oxidative stress by increasing the ability of a fish organism to adapt (Kharchenko et al., 2017b).

The results obtained in the current study can be correlated with the previous publications. The potential presence of naturally occurring antimicrobials in petals of Camellia japonica against foodborne pathogens in microbiological media and food was studied by Kim and co-workers (2001). Petals of the camellia flower were extracted with methanol and fractionated into basic, acidic, and neutral fractions. The acidic fraction produced an inhibitory zone of 14 to $19 \mathrm{~mm}$ (diameter) in a disk assay against the pathogens Salmonella typhimurium DT104, Escherichia coli 0157: H7, Listeria monocytogenes, and Staphylococcus aureus on agar plates. An aqueous extract from the petals of $C$. japonica had an inhibitory effect on the growth of all pathogens at $37^{\circ} \mathrm{C}$ in microbiological media by increasing the lag phase. None of the microorganisms was inhibited completely. Milk was used as a model food system. Aqueous extract at a concentration of $100 \mathrm{mg} / \mathrm{ml}$ was bacteriostatic against all the foodborne pathogens in the milk stored at $25^{\circ} \mathrm{C}$ for up to 4 days (Kim et al., 2001). Antimicrobial and anti-biofilm activities of the methanol extracts of Camellia japonica against dental pathogens Streptococcus mutans and Candida albicans were evaluated by Choi et al. (2017). As a result, it was found out that C. japonica significantly inhibited the growth of both bacteria by over 76\% (Choi et al., 2017).

Antimicrobial properties of fermented C. japonica leaf extracts against Gram-positive Staphylococcus epidermidis and Bacillus subtilis, and Gram-negative Klebsiella pneumonia and Escherichia coli bacteria were evaluated by disc diffusion method (Moon and Kim, 2018). Ethanol extracts showed higher antimicrobial activities against all bacterial strains tested with higher inhibitory effects on pancreatic lipase than methanol extracts. The results of this study highlight the possible use of fermented $C$. japonica leaf extracts as a source of antioxidant, antibacterial and antiobesity agents. Moreover, ethanol was recommended as a solvent for extracting antioxidants, antibacterial and antiobesity agents from this plant (Moon and Kim, 2018).

Synergistic combinations of antimicrobial agents with different mechanisms of action can be more successful strategies to combat infections involving multidrug-resistant (MDR) bacteria. In the study by Farooqui et al. (2015), the synergistic antimicrobial activity of Camellia sinensis and Juglans regia which are commonly used plants with different antimicrobial agents was studied. Antimicrobial susceptibility of $350 \mathrm{Gram}$-positive and Gram-negative strains belonging to 10 different bacterial species, was tested against Camellia sinensis and Juglans regia extracts. 
Camellia sinensis showed higher antibacterial activity against MDR Salmonella typhi than to other Gram-negative isolates. By testing a variety of clinical strains in a time-kill kinetic assay, Farooqui et al. (2015) further showed that green tea extract is bacteriostatic in nature and more efficient against MDR strains of $S$. typhi compared to pan-susceptible strains. Camellia sinensis also showed synergistic activity with nalidixic acid (FICI 0.37) against MDR S. typhi strains (Farooqui et al., 2015). The leave extracts of Camellia varieties indicated the presence of active biological compounds such as flavonoids, proteins, phenols, alkaloids and glycosides which exhibited strong activity against selected bacterial strains (Farooqui et al., 2015).

The crude extracts of six different plants of green tea Camellia assamica and Camellia sinensis were tested by Bashir et al. (2014) against three Gram-positive and four Gram-negative bacteria using the agar disk diffusion method at $50 \mathrm{mg} / \mathrm{ml}$ concentration. The maximum inhibition of Staphylococcus aureus was recorded by dimethyl sulphoxide extracts of green tea varieties. The measured zone of inhibition of dimethyl sulphoxide extracts by Qimen was $(10.00 \pm 0.0 \mathrm{~mm})$, Japanese $(10.00 \pm 0.0 \mathrm{~mm})$, Turkish $(10.00 \pm 0.0 \mathrm{~mm})$, Indonesian $(8.33$ $\pm 1.0 \mathrm{~mm}), \mathrm{P} 3$ clone $(10.00 \pm 0.0 \mathrm{~mm})$ and Sri Lankan $(10.00 \pm 0.0 \mathrm{~mm})$. Maximum scavenging potential activity was found with ethanol, methanol and dimethyl sulphoxide extracts. Spot screening indicated that the presence of active biological compounds such as flavonoids, proteins, phenols, alkaloids, and glycosides also exhibited strong activity against tested bacterial strains (Bashir et al., 2014).

Effect of tea extracts and standard flavanols against five pathogenic bacteria viz., Listeria monocytogenes (MTCC-839), Pseudomonas aeruginosa (MTCC-741), Bacillus cereus (MTCC1272), Staphylococcus aureus (MTCC-96) and Escherichia coli (MTCC-443), and eleven indigenous potential bacterial probiotics belonging to genera Enterococcus, Bacillus and Lactobacillus spp. obtained from fermented foods of Western Himalayas, was investigated by Sourabh et al. (2014). As is generally well known, the antimicrobial effect of plant extracts, including extract derived from Camellia spp. plants are closely associated with the content of secondary metabolites, such as phenolic and/or flavonoid compounds (Kang et al., 2003; Choi et al., 2017). In turn, the phenolic compound content is also closely related to the antioxidant activity of plant extracts.

Phenolic compounds of nutraceutical importance viz., catechins (C), (-)-epicatechin (EC), (-)-epigallocatechin (EGC), (-)-epigallocatechin-3-gallate (EGCG) and (-)-epicatechin-3-gallate (ECG) were also estimated in fresh green tea shoots of Camellia sinensis (L) 0 Kuntze cultivar. EGCG, ECG, and EGC exhibited antibacterial activity but, $\mathrm{C}$ and EC did not show this activity. It has been reported that tea extracts having high concentrations of EGCG and ECG were more potent in antibacterial action against bacterial pathogens. Tea extracts and standard flavan3-ols augmented viability of potential probiotics in an order of EGCG > EGC > ECG > EC > C. Tea extracts and standard flavanols had no antibacterial activity against Escherichia coli (MTCC-443) but, in combination with probiotic culture supernatants, this activity was seen (Sourabh et al., 2014).

Sharma et al. (2012) have explored the anti-microbial activity and the basic mechanism of aqueous green tea leaf extract on selected bacterial strains. Staphylococcus epidermidis, Micrococcus luteus, Brevibacterium linens, Pseudomonas fluorescens, and Bacillus subtilis were 
found to be sensitive to green tea extract via disc diffusion assay (zone of inhibition $\geq 7 \mathrm{~mm}$ ). The effect of aqueous extract on the adhesion of different bacteria to Vero cells indicated that it inhibits the adhesion at its minimum inhibitory concentration (MIC) value $(0.156-0.313 \mathrm{mg} / \mathrm{ml})$ (Sharma et al., 2012).

The use of natural plant materials such as green tea and rosemary could improve the microbial quality of foods in addition to their functional properties. The antimicrobial effects of green tea and rosemary added to foods as antagonists to foodborne pathogens were determined in laboratory media by Lee et al. (2009). The growth of each pathogen (Bacillus cereus, Salmonella typhimurium, Enterobacter sakazakii, Escherichia coli 0157: H7, Staphylococcus aureus, and Listeria monocytogenes) in tryptic soy broth or a rice cake with or without the addition of green tea or rosemary leaf powders before autoclaving or cooking, respectively, was investigated after inoculation. The addition of $1 \%$ green tea or rosemary produced similar results for inhibiting the growth of pathogens in tryptic soy broth. However, green tea was more effective than rosemary for inhibiting the growth of L. monocytogenes. Both botanicals had inhibitory effects against all pathogens tested in this study. Green tea was particularly effective against B. cereus, S. aureus, and $L$. monocytogenes, and rosemary was strongly inhibitory against B. cereus and $S$. aureus. The addition of 1 or $3 \%$ green tea or rosemary to rice cakes did not significantly reduce total aerobic counts; however, levels of $B$. cereus and $S$. aureus were significantly reduced in rice cakes stored for 3 days at room temperature (Lee et al., 2009).

Many of the direct effects of tea catechins are a result of the catechins binding to the bacterial lipid bilayer cell membrane which then causes damage to the membrane (Sirk et al., 2008, 2009; Reygaert, 2014). Molecular dynamics simulations were performed by Sirk et al. (2008) to study the interactions of bioactive catechins (flavonoids) commonly found in green tea with lipid bilayers, as a model for cell membranes. Simulations in the study of these researchers showed that the seven tea catechins evaluated had a strong affinity for the lipid bilayer via hydrogen bonding to the bilayer surface, with some of the smaller catechins able to penetrate underneath the surface. Epigallocatechin-gallate (EGCG) showed the strongest interaction with the lipid bilayer based on the number of hydrogen bonds formed with lipid headgroups (Sirk et al., 2008). The molecular structure and aggregated condition of the catechins significantly influence their absorption, as well as their ability to form hydrogen bonds with the lipid headgroups (Sirk et al., 2009). This damage can then lead to a variety of related antimicrobial effects.

Cho et al. (2007) have found that when exposed to Korean green tea (Camellia sinensis) polyphenols, the bacterial response of Escherichia coli was changed regulation of 17 individual genes. Nine upregulated proteins were identified (including GroEL and proteins involved in cellular defense, such as GyrA, RpoS, SodC, and EmrK), whereas the expression of eight proteins was downregulated by exposure to TPP (including proteins involved in carbon and energy metabolism, such as Eno, SdhA, and UgpQ, as well as those involved in amino-acid biosyntheses, such as GltK and TyrB). One of the major outcomes of this change in regulation was damage to the bacterial cell membrane (Cho et al., 2007). The catechins primarily act on and damage bacterial membranes. The observation that Gram-negative bacteria are more resistant to bactericidal catechins than Gram-positive bacteria can be explained to some 
extent by the presence of negatively charged lipopolysaccharide (Ikigai et al., 1993). Bacterial cell membrane damage inhibits the ability of the bacteria to bind to host cells (Sharma et al., 2012), and inhibits the ability of the bacteria to bind to each other to form biofilms, which are significant in pathogenesis (Blanco et al., 2005).

Recently, a 'green method' for the synthesis of gold nanoparticles (AuNPs) has been reported by Sharma et al. (2019), where C. japonica leaves extract was used as a reducing agent. Furthermore, the resulting antimicrobial activity of the synthesized AuNPs was tested against seven different microbial strains such as Bacillus subtilis, Staphylococcus aureus, Streptococcus faecalis, Klebsiella pneumoniae, Pseudomonas aeruginosa, Escherichia coli, and Candida albicans. The AuNPs showed a moderate activity at the dosage rate of $200 \mu \mathrm{g} / \mathrm{mL}$ (Sharma et al., 2019). The antimicrobial action of gold nanoparticles against Gram-positive and Gram-negative bacterial strains was explained by Shamaila et al. (2016). For the Grampositive bacteria the structure of the membrane, i.e., the peptidoglycan layer's thickness, which is an important part of pathogenic bacteria, is 50\% higher than in Gram-negative bacteria. Consequently, larger doses of nanoparticles are required for Gram-positive bacteria (Shamaila et al., 2016).

Bacterial membrane damage also results in an inability of the bacteria to be able to secrete toxins (Sugita-Konishi et al., 1999; Shah et al., 2008). Production and extracellular release of maltose-binding protein, a periplasmic protein, was also inhibited by epigallocatechin gallate (EGCg) and gallocatechin gallate (GCg), indicating that their inhibitory effect on release from the periplasm into the outer milieu is not specific to Vero toxins (VTs) from enterohemorrhagic Escherichia coli (EHEC), but general to the proteins accumulated in EHEC periplasm (SugitaKonishi et al., 1999). The observation that secretion of key components of Staphylococcal virulence in study of Shah et al. (2008) can be compromised by a naturally occurring polyphenol supports the notion that (-)-epicatechin gallate (ECg) and related compounds may have therapeutic utility for the control of infections that are currently difficult to treat due to the propensity of methicillin-resistant $S$. aureus to accumulate antibiotic resistance genes.

Zhang and Rock (2004) have found that green tea components (especially EGCG) inhibit specific reductases (FabG, FabI) in bacterial type II fatty acid synthesis. The presence of the galloyl moiety was essential for activity, and EGCG was a competitive inhibitor of FabI and a mixed type inhibitor of FabG demonstrating that EGCG interfered with cofactor binding in both enzymes. EGCG inhibited acetate incorporation into fatty acids in vivo, although it was much less potent than thiolactomycin, a validated fatty acid synthesis inhibitor. Inhibition of fatty acid synthesis by green tea has also been found to inhibit bacterial production of toxic metabolites. The inhibitory effect on the production of toxic end metabolites of bacteria can be attributed to the presence of the galloyl moiety, which is ester-linked with the 3-OH of the catechin moiety in the polyphenolic compounds (Sakanaka and Okada, 2004).

Okamoto et al. $(2003,2004)$ also found that green tea catechins have an inhibitory effect on protein tyrosine phosphatase and cysteine proteinases in certain anaerobic oral bacteria (Prevotella intermedia, Porphyromonas gingivalis). The inhibitory effect observed is due to the presence of galloyl moiety in the structure (Okamoto et al., 2003, 2004). 
The catechins inhibit bacterial DNA gyrase by binding to the ATP binding site of the gyrase B subunit. In the group of four tested catechins, epigallocatechin gallate (EGCG) had the highest activity, followed by epicatechin gallate (ECG) and epigallocatechin (EGC) (Grandišar et al., 2007). The green tea polyphenols can inhibit the enzyme dihydrofolate reductase in bacteria and yeast, effectively blocking the ability of the microorganisms to synthesize folate. In elucidating its mechanism of action, Navarro-Martínez et al. (2005) have shown that epigallocatechin gallate is an efficient inhibitor of Stenotrophomonas maltophilia dihydrofolate reductase (Navarro-Martinez et al., 2005). EGCG also acts as an antifolate compound on Candida albicans, disturbing its folic acid metabolism (Navarro-Martinez et al., 2006). The bioflavonoids obtained from green tea could also inhibit the activity of bacterial ATP synthase, reducing the ability of the microorganisms to produce enough energy (Chinnam et al., 2010).

\section{Conclusions}

Based on our current investigations it can be concluded that Camellia japonica and its cultivars possess a mild antibacterial efficacy. It may also be concluded that the antimicrobial potential of various samples of these plants might be due to a wide variety of compounds present in these plants. The findings reported herein give scientific credence to the traditional uses of these plants and suggest that extracts derived from the leaves of Camellia japonica and its cultivars merit further chemical study as natural antibiotics to identify the secondary metabolites.

\section{Acknowledgments}

This study was carried out during the Scholarship Program supported by The Polish National Commission for UNESCO in the Institute of Biology and Earth Sciences, Pomeranian University in Slupsk (Poland). We thank The Polish National Commission for UNESCO for providing support for our study.

\section{References}

AKIHISA, T., YASUKAWA, K., KIMURA, Y., TAKASE, S., YAMANOUCHI, S., TAMURA, T. 1997. Triterpene alcohols from camellia and sasanqua oils and their anti-inflammatory effects. In Chem. Pharm. Bull. (Tokyo), vol. 45, p. 2016-2023. https://doi.org/10.1248/cpb.45.2016

BASHIR, S., KHAN, B.M., BABAR, M., ANDLEEB, S., HAFEEZ, M., ALI, S., KHAN, M.F. 2014. Assessment of Bioautography and Spot Screening of TLC of Green Tea (Camellia) Plant Extracts as Antibacterial and Antioxidant Agents. In Indian J. Pharm. Sci., vol. 76(4), p. 364-370.

BAUER, A.W., KIRBY, W.M., SHERRIS, J.C., TURCK, M. 1966. Antibiotic susceptibility testing by a standardized single disk method. In Am. J. Clin. Pathol., vol. 45(4), p. 493-496.

BLANCO, A.R., SUDANO-ROCCARO, A., SPOTO, G.C., NOSTRO, A., RUSCIANO, D. 2005. Epigallocatechin gallate inhibits biofilm formation by ocular staphylococcal isolates. In Antimicrob. Agents Chemother., vol. 49(10), p. 4339-4343. https://doi.org/10.1128/AAC.49.10.4339-4343.2005

CARRANZA, M.G., SEVIGNY, M.B., BANERJEE, D., FOX-CUBLEY, L. 2015. Antibacterial activity of native California medicinal plant extracts isolated from Rhamnus californica and Umbellularia californica. In Ann. Clin. Microbiol. Antimicrob., vol. 14, p. 29. https://doi.org/10.1186/s12941-015-0086-0

CHACKO, S.M., THAMBI, P.T., KUTTAN, R., NISHIGAKI, I. 2010. Beneficial effects of green tea: a literature review. In Chin. Med., vol. 5, p. 13. https://doi.org/10.1186/1749-8546-5-13

CHINNAM, N., DADI, P.K., SABRI, S.A., AHMAD, M., KABIR, M.A., AHMAD, Z. 2010. Dietary bioflavonoids inhibit Escherichia coli ATP synthase in a differential manner. In Int. J. Biol. Macromol., vol. 46(5), p. 478-486. https://doi.org/10.1016/j.ijbiomac.2010.03.009 
CHO, Y.S., SCHILLER, N.L., KAHNG, H.Y., OH, K.H. 2007. Cellular responses and proteomic analysis of Escherichia coli exposed to green tea polyphenols. In Curr. Microbiol., vol. 55(6), p. 501-506. https://doi.org/10.1007/s00284-007-9021-8

CHOI, H.-A., CHEONG, D.-E., LIM, H.-D., KIM, W.-H., HAM, M.-H., OH, M.-H., WU, Y., SHIN, H.-J., KIM, G.J. 2017. Antimicrobial and Anti-Biofilm Activities of the Methanol Extracts of Medicinal Plants against Dental Pathogens Streptococcus mutans and Candida albicans. In J. Microbiol. Biotechnol., vol. 27(7), p. 1242-1248. https://doi.org/10.4014/jmb.1701.01026

CLSI. Performance Standards for Antimicrobial Susceptibility Testing. Clinical and Laboratory Standards Institute; Wayne, PA, USA: 2014. CLSI M100-S24.

DAVIN-REGLI, A., LAVIGNE, J.P., PAGÈS, J.M. 2019. Enterobacter spp.: Update on Taxonomy, Clinical Aspects, and Emerging Antimicrobial Resistance. In Clin. Microbiol. Rev., vol. 32(4), pii: e00002-19. https://doi.org/10.1128/CMR.00002-19

DAVIN-REGLI, A., PAGÈS, J.M. 2015. Enterobacter aerogenes and Enterobacter cloacae; versatile bacterial pathogens confronting antibiotic treatment. In Front Microbiol., vol. 6, p. 392. https://doi. org/10.3389/fmicb.2015.00392

FABRICANT, D.S., FARNSWORTH, N.R. 2001. The value of plants used in traditional medicine for drug discovery. In Environ. Health Perspect., vol. 109 (1), p. 69-75. https://doi.org/10.1289/ ehp.01109s169

FARNSWORTH, N.R. 1990. The role of ethnopharmacology in drug development. In Ciba Found Symp., vol. 154, p. 2-11.

FAROOQUI, A., KHAN, A., BORGHETTO, I., KAZMI, S.U., RUBINO, S., PAGLIETTI, B. 2015. Synergistic antimicrobial activity of Camellia sinensis and Juglans regia against multidrug-resistant bacteria. In PLoS One, vol. 10(2), p. e0118431. https://doi.org/10.1371/journal.pone.0118431

FASSINA, G., BUFFA, A., BENELLI, R., VARNIER, O.E., NOONAN, D.M., ALBINI, A. 2002. Polyphenolic antioxidant (-)-epigallocatechin-3-gallate from green tea as a candidate anti-HIV agent. In AIDS, vol. 16(6), p. 939-941. https://doi.org/10.1097/00002030-200204120-00020

GAO, J.Y., PARKS, C.R., DU, Y.Q. 2005. Collected species of the genus Camellia and illustrated outline. Zhejiang: Zhejiang Science and Technology Press.

GRADISAR, H., PRISTOVSEK, P., PLAPER, A., JERALA, R. 2007. Green tea catechins inhibit bacterial DNA gyrase by interaction with its ATP binding site. In J. Med. Chem., vol. 50(2), p. 264-271. https://doi. org/10.1021/jm060817o

IKIGAI, H., NAKAE, T., HARA, Y., SHIMAMURA, T. 1993. Bactericidal catechins damage the lipid bilayer. In Biochim. Biophys. Acta, vol. 1147(1), p. 132-136. https://doi.org/10.1016/0005-2736(93)90323-r

KANG, D.G., YUN, C.K., LEE, H.S. 2003. Screening and comparison of antioxidant activity of solvent extracts of herbal medicines used in Korea. In J. Ethnopharmacol., vol. 87, p. 231-236. https://doi. org/10.1016/s0378-8741(03)00142-9

KHAN, I., ABBAS, T., ANJUM, K., ABBAS, S.Q., SHAGUFTA, B.I., SHAH, S.A.A., AKHTER, N., HASSAN, S.S. 2019. Antimicrobial potential of aqueous extract of Camellia sinensis against representative microbes. In Pak. J. Pharm. Sci., vol. 32(2), p. 631-636.

KHAN, N., MUKHTAR, H. 2007. Tea polyphenols for health promotion. In Life Sciences, vol. 81(7), p. 519-533. https://doi.org/10.1016/j.lfs.2007.06.011

KHARCHENKO, I., MARYNIUK, M., BUYUN, L., TKACHENKO, H., PAŻONTKA-LIPIŃSKI, P., WITASZEK, M., OSADOWSKI, Z. 2017a. Lipid peroxidation level in the muscle tissue of the rainbow trout (Oncorhynchus mykiss Walbaum) under in vitro incubation with extracts from leaves of various cultivars of Camellia japonica L. (Theaceae). In Naukovo-tekhnichnyi biuleten, Instytut tvarynnytstva, Nats. akad. ahrar. nauk Ukrainy. Kharkiv, vol. 118, p. 3-13.

KHARCHENKO, I., MARYNIUK, M., TKACHENKO, H., BUYUN, L., PAŻONTKA-LIPIŃSKI, P., WITASZEK, M., OSADOWSKI, Z. 2018. Superoxide dismutase activity level in the muscle tissue of the rainbow trout (Oncorhynchus mykiss Walbaum) as a biomarker of antioxidant properties of leaf extracts 
of Camellia japonica L. cultivars (Theaceae). In Fishery reservoirs of Russia: fundamental and applied research: Proceedings of the II All-Russian Scientific Conference with International Participation, FGBIU „L.S. Berg State Research Institute of the Lake and River Fisheries» (FGBNU «GosNIORH»), St. Petersburg, p. 528-535.

KHARCHENKO, I., MARYNIUK, M., TKACHENKO, H., BUYUN, L., PAŻONTKA-LIPIŃSKI, P., WITASZEK, M., OSADOWSKI, Z. 2017b. Total antioxidant activity of the muscle tissue of the rainbow trout (Oncorhynchus mykiss Walbaum) under incubation with extracts from leaves of various cultivars of Camellia japonica L. In Scientific Journal of DALRYBVTUZ, vol. 43(4), p. 18-26.

KIM, K.Y., DAVIDSON, P.M., CHUNG, H.J. 2001. Antibacterial activity in extracts of Camellia japonica L. petals and its application to a model food system. In J. Food Prot., vol. 64(8), p. 1255-1260. https:// doi.org/10.4315/0362-028x-64.8.1255

LEE, S.Y., GWON, S.Y., KIM, S.J., MOON, B.K. 2009. Inhibitory effect of commercial green tea and rosemary leaf powders on the growth of foodborne pathogens in laboratory media and oriental-style rice cakes. In J. Food Prot., vol. 72(5), p. 1107-1111. https://doi.org/10.4315/0362-028x-72.5.1107

MAHMOOD, T., AKHTAR, N., KHAN, B.A. 2010. The morphology, characteristics and medicinal properties of Camellia sinensis' tea. In Journal of Medicinal Plants Research, vol. 4(19), p. 2028-2033. https:// doi.org/10.5897/JMPR10.010

MEZZATESTA, M.L., GONA, F., STEFANI, S. 2012. Enterobacter cloacae complex: clinical impact and emerging antibiotic resistance. In Future Microbiol., vol. 7(7), pp. 887-902. https://doi. org/10.2217/fmb.12.61

MOON, S.H., KIM, M.Y. 2018. Phytochemical profile, antioxidant, antimicrobial and antipancreatic lipase activities of fermented Camellia japonica L. leaf extracts. In Tropical Journal of Pharmaceutical Research, vol. 17(5), p. 905-912. http://dx.doi.org/10.4314/tjpr.v17i5.22

NAVARRO-MARTÍNEZ, M.D., GARCÍA-CÁNOVAS, F., RODRÍGUEZ-LÓPEZ, J.N. 2006. Tea polyphenol epigallocatechin-3-gallate inhibits ergosterol synthesis by disturbing folic acid metabolism in Candida albicans. In J. Antimicrob. Chemother., vol. 57(6), p. 1083-1092. https://doi.org/10.1093/ jac/dkl124

NAVARRO-MARTÍNEZ, M.D., NAVARRO-PERÁN, E., CABEZAS-HERRERA, J., RUIZ-GÓMEZ, J., GARCÍACÁNOVAS, F., RODRÍGUEZ-LÓPEZ, J.N. 2005. Antifolate activity of epigallocatechin gallate against Stenotrophomonas maltophilia. Antimicrob. In Agents Chemother., vol. 49(7), p. 2914-2920. https://doi.org/10.1128/AAC.49.7.2914-2920.2005

OKAMOTO, M., LEUNG, K.P., ANSAI, T., SUGIMOTO, A., MAEDA, N. 2003. Inhibitory effects of green tea catechins on protein tyrosine phosphatase in Prevotella intermedia. In Oral Microbiol. Immunol., vol. 18(3), p. 192-195. https://doi.org/110.1034/j.1399-302x.2003.00056.x

OKAMOTO, M., SUGIMOTO, A., LEUNG, K.P., NAKAYAMA, K., KAMAGUCHI, A., MAEDA, N. 2004. Inhibitory effect of green tea catechins on cysteine proteinases in Porphyromonas gingivalis. In Oral Microbiol. Immunol., vol. 19(2), p. 118-120. https://doi.org/10.1046/j.0902-0055.2003.00112.x

OKOTH, D.A., CHENIA, H.Y., KOORBANALLY, N.A. 2013. Antibacterial and antioxidant activities of flavonoids from Lannea alata (Engl.) Engl. (Anacardiaceae). In Phytochem. Lett., vol. 6, 476-481. https://doi.org/10.1016/j.phytol.2013.06.003

ONODERA, K., HANASHIRO, K., YASUMOTO, T. 2016. Camellianoside, a novel antioxidant glycoside from the leaves of Camellia japonica. In Biosci. Biotechnol. Biochem., vol. 70, p. 1995-1998. https://doi. org/10.1271/bbb.60112

PARK, J.C., HUR, J.M., PARK, J.G., HATANO, T., YOSHIDA, T., MIYASHIRO, H., MIN, B.S., HATTORI, M. 2002. Inhibitory effects of Korean medicinal plants and camelliatannin $\mathrm{h}$ from Camellia japonica on human immunodeficiency virus type 1 protease. In Phytother. Res., vol. 16, p. 422-426. https://doi. org/10.1002/ptr.919

RAMAKRISHNA, A., RAVISHANKAR, G.A. 2011. Influence of abiotic stress signals on secondary metabolites in plants. In Plant Signal. Behav., vol. 6(11), p. 1720-1731. https://doi.org/10.4161/ psb.6.11.17613 
REDDICK, L.E., ALTO, N.M. 2014. Bacteria fighting back: how pathogens target and subvert the host innate immune system. In Mol. Cell, vol. 54(2), p. 321-328. https://doi.org/10.1016/j.molcel.2014.03.010

REYGAERT, W.C. 2014. The antimicrobial possibilities of green tea. In Front Microbiol., vol. 5, p. 434. https://doi.org/10.3389/fmicb.2014.00434

SAKANAKA, S., OKADA, Y. 2004. Inhibitory effects of green tea polyphenols on the production of a virulence factor of the periodontal-disease-causing anaerobic bacterium Porphyromonas gingivalis. In J. Agric. Food Chem., vol. 52(6), p. 1688-1692. https://doi.org/10.1021/if0302815

SHAH, S., STAPLETON, P.D., TAYLOR, P.W. 2008. The polyphenol (-)-epicatechin gallate disrupts the secretion of virulence-related proteins by Staphylococcus aureus. In Lett. Appl. Microbiol., vol. 46(2), p. 181-185. https://doi.org/10.1111/j.1472-765X.2007.02296.x

SHAMAILA, S., ZAFAR, N., RIAZ, S., SHARIF, R., NAZIR, J., NASEEM, S. 2016. Gold nanoparticles: an efficient antimicrobial agent against enteric bacterial human pathogen. In Nanomaterials, vol. 6(71), p. 1-10. https://doi.org/10.3390/nano6040071

SHARMA, A., GUPTA, S., SARETHY, I.P., DANG, S., GABRANI, R. 2012. Green tea extract: possible mechanism and antibacterial activity on skin pathogens. In Food Chem., vol. 135(2), p. 672-675. https://doi. org/10.1016/j.foodchem.2012.04.143

SHARMA, T.S.K., SELVAKUMAR, K., HWA, K.Y., SAMI, P., KUMARESAN, M. 2019. Biogenic fabrication of gold nanoparticles using Camellia japonica L. leaf extract and its biological evaluation. In Journal of Materials Research and Technology, vol. 8(1), p. 1412-1418. https://doi.org/10.1016/j. imrt.2018.10.006

SIRK, T.W., BROWN, E.F., FRIEDMAN, M., SUM, A.K. 2009. Molecular binding of catechins to biomembranes: relationship to biological activity. In J. Agric. Food Chem., vol. 57(15), p. 6720-6728. https://doi. org/10.1021/jf900951w

SIRK, T.W., BROWN, E.F., SUM, A.K., FRIEDMAN, M. 2008. Molecular dynamics study on the biophysical interactions of seven green tea catechins with lipid bilayers of cell membranes. In J. Agric. Food Chem., vol. 56(17), p. 7750-7758. https://doi.org/10.1021/if8013298

SOURABH, A., KANWAR, S.S., SUD, R.G., GHABRU, A., SHARMA, O.P. 2014. Influence of phenolic compounds of Kangra tea [Camellia sinensis (L.) O Kuntze] on bacterial pathogens and indigenous bacterial probiotics of Western Himalayas. In Braz. J. Microbiol., vol. 44(3), p. 709-715. https://doi. org/10.1590/s1517-83822013000300007

SUGITA-KONISHI, Y., HARA-KUDO, Y., AMANO, F., OKUBO, T., AOI, N., IWAKI, M., KUMAGAI, S. 1999. Epigallocatechin gallate and gallocatechin gallate in green tea catechins inhibit the extracellular release of Vero toxin from enterohemorrhagic Escherichia coli 0157: H7. In Biochim. Biophys. Acta, vol. 1472(1-2), p. 42-50. https://doi.org/10.1016/s0304-4165(99)00102-6

THAO, N.T., HUNG, T.M., LEE, M.K., KIM, J.C., MIN, B.S., BAE, K. 2010. Triterpenoids from Camellia japonica and their cytotoxic activity. In Chem. Pharm. Bull. (Tokyo), vol. 58, p. 121-124. https://doi. org/10.1248/cpb.58.121

VIJAYAN, K., ZHANG, W., TSOU, C. 2009. Molecular taxonomy of Camellia (Theaceae) inferred from nrITS sequences. In Am J Bot., vol. 96(7), p. 1348-1360. https://doi.org/10.3732/ajb.0800205

YANG, J.B., YANG, S.X., LI, H.T., YANG, J., LI, D.Z. 2013. Comparative chloroplast genomes of Camellia species. In PLoS One, vol. 8(8), p. e73053. https://doi.org/10.1371/journal.pone.0073053

YOON, I.S., PARK, D.H., KIM, J.E., YOO, J.C., BAE, M.S., OH, D.S., SHIM, J.H., CHOI, C.Y., AN, K.W. 2017. Identification of the biologically active constituents of Camellia japonica leaf and anti-hyperuricemic effect in vitro and in vivo. In Int. J. Mol. Med., vol. 39, p. 1613-1620.

ZAR, J.H. 1999. Biostatistical Analysis. $4^{\text {th }}$ ed., Prentice-Hall Inc., Englewood Cliffs, New Jersey.

ZHANG, Y.M., ROCK, C.O. 2004. Evaluation of epigallocatechin gallate and related plant polyphenols as inhibitors of the FabG and FabI reductases of bacterial type II fatty-acid synthase. In J. Biol. Chem., vol. 279(30), p. 30994-31001. https://doi.org/10.1074/ibc.M403697200 